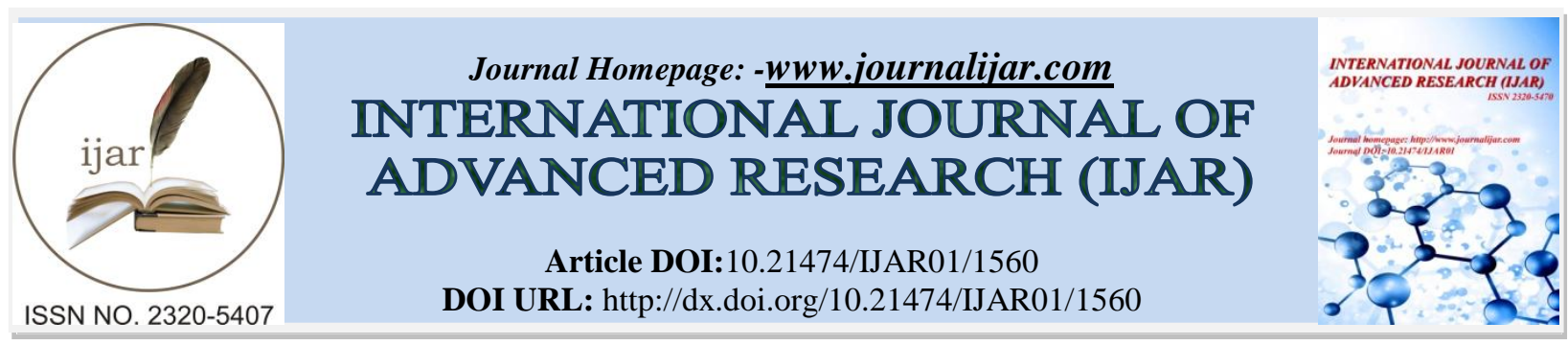

RESEARCH ARTICLE

\title{
THE INFLUENCE OF LEARNING MOTIVATION ON SELF STUDY OF THIRD YEAR MEDICAL STUDENTS
}

N Juni Triastuti.

Faculty of Medicine, Universitas Muhammadiyah Surakarta, Indonesia. Email : Juni.triastuti@ums.ac.id.

\section{Manuscript Info}

Manuscript History

Received: 12 July 2016

Final Accepted: 21 August 2016

Published: September 2016

Key words:-

learning motivation, self-study.

\section{Abstract}

The amount of self-study is one of factors for obtaining the success in the learning process in medical education for which student can achieve a satisfactory academic performance. This study analyze the influence of learning motivation on self-study of the medical students. The research involved 88 respondents who received a questionnaire on learning motivation. The data then were analyzed using independent $\mathrm{t}$ test.There is a significant correlation between learning motivation and self study with mean differences of $0,68 \pm 0,32$ and $t$ value of 2,123 (p: 0,037). In overall, there is a significant relationship between learning motivation towards self-study in the third year of medical students.

Copy Right, IJAR, 2016,. All rights reserved.

\section{Introduction:}

The medical education development is now changed from Teacher-Centered Learning (TCL) to Student-Centered Learning (SCL) inthe way of teaching and learning. This is the consideration for successful in study at Faculty of Medicine to implement SCL in curriculum. In the conventional of teaching learning approach that is TCL, lecturers are considered very influential in determining student learning. Lecturers are also very essential in the control of the learning process of students. In the other side, curriculum using Student Centered Learning approach such as Problem Based Learning (PBL), students are encouraged to conduct self-study. The amount of self-study then is considered as one of the successful for obtaining the excellent learning achievement.

Complaints of third year students said that they are having less score for the academic achievement due to having less motivation.As presented by Knowles, (1975) stated thatstudents without have the readiness for self-study will experience anxiety, frustration, and low motivation then will failure to achieve the expected performance. Furthermore, in the theory of Thorndike revealed that students will face learning environment that demands students to be self-reliance and active therefore the learning process will eventually be success. Hence the amount of selfstudy of students enrolled in the PBL approach is absolutely required to maximize the learning process independently. Student readiness in implementing self-study will greatly influence the learning process of students in the tutorial in whichproblems in it serve to provoke creativity and curiosity of students to learn more material related.

The acceptance rate among accepted and applicant in the faculty of medicine University of Muhammadiyah Surakarta is high which constitute 1:12 which students are expected to be successful in the medical education. However; in reality; there is also an evidence that the final test scores are less satisfactory. This problem is prompted by the author to see how the motivation of the third level medical students and how much time they conduct the self- 
study. Researchers assume that a high motivation of students will encourage student to spend more time to conduct self-study that will result in higher academic achievement as well.

The formulation of the problem in this research is that whether there is an influence of learning motivation on selfstudy of the third year of medical students. The purpose of this study is knowing the influence of learning motivation on self-study of medical students in the third year. This research is expected to benefit students in developing study time and learning motivation forbetter learning process.For the institutions from which the research results can be obtained information about learning motivation and self-study picture of the third year medical students. Artist and Harris, (2007) stated that the factors in developing self learning including an understanding of the subject matter in advance (prior knowledge), independent learning skills, motivation to learn independently.

Furthermore, statement ofRantenstrauch, (2001) cited by Bohne, Faltin, Wagner, (2002), stated that in order to be able to perform self-learning, a student must have a competency of self-observation, self-reflection, selfjudgment,making their own objective, doing reactivation of existing knowledge,managing learning autonomy (e.g.: time management to study), buildinglearning motivation and concentration in learning autonomy to determine their own learning strategies and problem solving strategies, understanding when to seek a help from a friend or tutor. Knowles, (1975);Slevin and Lavery; (1991);Miflin et al., (2000) stated that the faculty and learning environment affect the self-directed learning.

\section{Methods:-}

This research was a cross-sectional design with the dependent variable of self-stuy.Data of independent variables including learning motivation taken by distributing questionnaires. Quantitative research data were analyzed using descriptive statistics and inferential statistics. Descriptive statistics were used to investigate average value, standard deviation (SD), minimum and maximum values of the variables of the study. Inferential statistics are used to determine the relationship oflearning motivation towards self-study. Relationship within the two variables was assessed using independent t test (Sugiyono, 2011; Johnson \& Christensen, 2008; Creswell, 1994).

The subjects were selected using purposive technical sampling for the third year students at the Faculty of Medicine, UniversitasMuhammadiyah Surakarta in the academic year 2016. All subjects who meet the inclusion criteria of the third-year medical students, present at the time of the study and willing to be respondents. Exclusion criteria were the third year students who were not present at the time of the study and were not collectingquestionnaire or filling questionnaire incomplete.

The data that collected in this research including primary data. Primary data was taken by distributing questionnaires to students. The questionnaire used scales including the Questionnaire Motivated Strategies for Learning Questionnaire (MSLQ) developed by the National Center for Research to Improve Postsecondary Teaching and Learning, University of Michigan (Suhoyo, Y. 2008). Data analysis techniques used in this study is the analysis of quantitative data analysis that consisted of descriptive statistics. Then,it will be followed by independent $t$ test. Descriptive statistical analysis aimed to determine the average value, standard deviation (SD), minimum and maximum values of the variables of the research (Johnson \& Christensen, 2008).

\section{Results and Discussion:-}

Researchinvestigation of the influence of learning motivation on self-study by distributing questionnaires. Questionnaire of the Motivated Strategies for Learning Questionnaire (MSLQ) given to third year students at the Faculty of Medicine of the academic year 2015/2016. Furthermore, the data after analyzing used SPSS Ver.23 were obtained as follows:

Table 1:- Distribution of learning motivation and self-study $(\mathrm{n}=88)$

\begin{tabular}{|l|l|l|l|l|l|}
\hline Variable & Mean & Median & Mode & Minimum & Maximum \\
\hline Learning motivation & 95,32 & 93,5 & 91 & 42 & 126 \\
\hline Self-study(hours) & 2,52 & 2 & 2 & 0,5 & 8 \\
\hline
\end{tabular}

Data that meeting the inclusion and exclusion criteria were as many as 88 . The table above shows that the average learning motivation in the third level is equal to 95,32. The average of self-study is obtained by 2,52 hours. The 
minimum value of the students's learning motivationis 42 while the maximum value of learning motivation is 126. Minimum time spend for self-studyis 0,5 hours while the maximum time spend for self-study is 8 hours. The average learning motivation score of third level medical student is considered in high level which constitute for 95,32 which could predict to higher academic achievement.

The data then analyzed using independent $t$ test, the analyzes were drawn below :

Table 2:-The differences of learning motivation and self-study $(\mathrm{n}=88)$.

\begin{tabular}{|c|l|l|l|l|l|l|}
\hline Variable & $\mathrm{N}$ & Mean & $\begin{array}{l}\text { Mean } \\
\text { differences }\end{array}$ & $\mathrm{t}$ cal & $\mathrm{t}$ table & $\mathrm{p}$ value \\
\hline Self-study -Motivation $\geq 93,5$ & 44 & 2,86 & $0,6 \pm 0,32$ & 2,123 & 2,660 & 0,037 \\
\hline -Motivation $<93,5$ & 44 & 2,18 & & & & \\
\hline
\end{tabular}

From table 2 above, it is known that there is mean differences of self-study on learning motivation which constitute for $0,6 \pm 0,32$. Meanwhile, the $t$ calculated is 2,123 which is less than table of 2,660 that indicating that there is significant differences of self-study based on learning motivation. This means that there is an influence of learning motivation on self-study of medical student's. This correlation indicates that the higher the level of learning motivation, the longerself-study will be. The study is in line with Rhoads, K., and deHaan, J. (2013); Mezei G., 2008; Marcou, A. and Philippou, G. (2005); Kan’an, A., and Osman K. (2015); Evans A. and Maiyo J.K.(2015); Sunanto, 2006. Meanwhile, Marcou and Philippou (2005); Harden RM (2005) revealed that learning motivation is consisting three factors that including (a) self-efficacy, (b)task value dan (c) goal orientation. Learning motivation drives students to spend more their time for learning that will then influence the successful of study in the medical education.

\section{Conclusion:-}

Based on the research result, it is found that there is a significant correlation between learning motivation and selfstudy of third year medical students.

\section{References:-}

1. Artist A, Harris E. . (2007) Self-Directed Learning And Sales Force Performance: An Integrated Framework. J Personal Selling Sales Manage; 27 (1) :9-24.

2. Bohne A, Faltin N, Wagner B (2002), Self-directed Learning and Tutorial Assistance in a Remote Laboratory, Learning Lab Lower Saxony (L3S) in Interactive Computer Aided Learning Conference, September 25-27, Austria. Available from; http://www-Ita.disco.unimib.it/quac/docs/unifi.forms.2003.pdf

3. Creswell, (1994), Research Design: Qualitative and Quantitative Approaches, Sage Publications, London.

4. Evans A. and Maiyo J.K.(2015). Study Of The Relationship Between Study Habits And Academic Achievement Of Students: A Case Of Spicer Higher Secondary School, India International Journal of Educational Administration and Policy Studies. Vol. 7(7), pp. 134-141, September, 2015 DOI: 10.5897/IJEAPS2015.0404 Article Number: A18769055459 ISSN $2141-6656$. http://www.academicjournals.org/IJEAPS

5. Harden RM (2005), A Practical Guide for Medical Teachers, Elsevier Churchill Livingstone, London.

6. Johnson and Christensen, (2008) Educational Research: Quantitative, Qualitative and Mixed Approaches, Sage Publications, United States of America.

7. Kan'an, A., and Osman K. (2015). The Relationship between Self-Directed Learning Skills and Science Achievement among Qatari Students. Creative Education, 6, 790-797. http://dx.doi.org/10.4236/ce.2015.68082

8. Knowles M. (1975.) Self-directed learning.A Guide for Learners and Teachers. Cambridge, NY: Cambridge Adult Learning Pearson Education;

9. Marcou, A. and Philippou, G. (2005) Motivational Beliefs, Self-Regulated Learning And Mathematical Problem Solving. In Chick, H. L. \& Vincent, J.L. (Eds.).Proceedings of the 29th Conference of the International Group for the Psychology of Mathematics Education (Internet). Vol.3, pp 297-304. Melbourne: PME. Availablefrom:http://www.emis.de/proceedings/PME29/PME29RRPapers/PME29Vol3MarcouPhilippou.pdf

10. Mezei G., 2008. Motivation And Self-Regulated Learning: A Case Study Of A Pre-Intermediate AndAn UpperIntermediate Adult Student. Wopalp Vol. 2 Pp 79.

11. Miflin BM, Campbell CB, Price DA. . (2000) A Conceptual Framework To Guide The Development Of SelfDirected, Lifelong Learning In ProblemBased Medical Curricula. Med Educ; 34 (4) :299-306. 
12. Rhoads, K., \& deHaan, J. (2013). Enhancing Student Self-Study Attitude And Activity With Motivational Techniques. Studies in Self-Access Learning Journal, 4(3), 175-195.

13. Slevin OD, MC Lavery. (1991) Self-Directed Learning And Student Supervision.NursEducToday.; 11 (5) :36877.

14. Sugiyono, 2011. Statistics For Research. Alfabeta. Bandung.

15. Sunanto, 2006, TheRelationship Between Learning Motivation, Attitudes Toward Teachers, Learning Styles And Achievement Learn Indonesian Seventh Grade Students Of SMP Negeri10 Bandar Lampung Academic Year 2004/2005. http://digilib.unila.ac.id/go.php?id=laptunilapp-gdl-s2-2006-sunanto516

16. Suhoyo, Y. (2008) Efficacy Comparison between Computer-based Learning (CBL) and the Lecture as Teaching Basic Principles of Bioethics at the Faculty of Medicine of New Students. Master of Science Thesis Medical Education Faculty of Medicine, University 